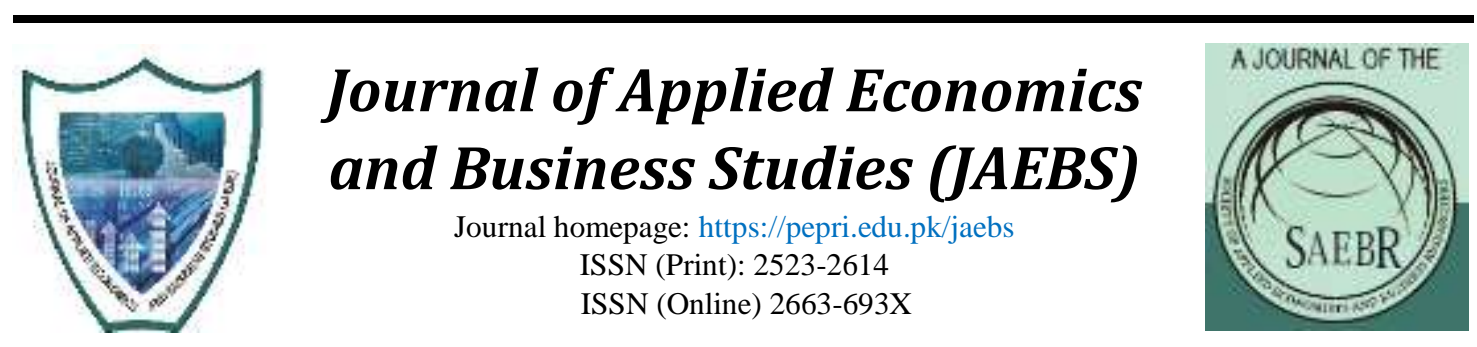

\title{
Consumers' Willingness to Pay for Fresh-Water Grown Leafy Vegetables
}

Salah Udin Buzdar ${ }^{1}$, Syed Muhammad Khair ${ }^{2}$ and Syed Munawar Shah ${ }^{3 *}$

${ }^{1}$ Government Postgraduate College Saryab Road, Quetta, Pakistan

${ }^{2}$ Department of Economics, BUITEMS University, City Campus Jinnah Town Quetta

${ }^{3}$ Department of Economics, BUITEMS University, City Campus Jinnah Town Quetta

\begin{abstract}
Wastewater-grown vegetables are responsible for various diseases whereas freshwater-grown vegetables are comparatively expensive. This paper examines consumers' willingness to pay for freshwater grown leafy vegetables, such as, cauliflower, spinach and salad. For this purpose, a survey was conducted in five selected areas of Quetta city using contingent valuation method and 255 vegetable-consumers were questioned directly with the help of a semi-structured questionnaire. The results indicate that most of the vegetable consumers (87-88\%) are willing to pay extra amounts for $F W G V$. On average, a vegetable consumer is willing to pay $27.4 \%, 43 \%$ and $52 \%$ more than the original price for the three leafy vegetables (cauliflowers, salads and spinaches, respectively). The factors such as household income, level of education, awareness, use of freshwater-grown vegetables and employment were identified as determinants of consumers' willingness to pay for FWGV. The study results reveal a high willingness to pay for FWGV by the vegetable consumers and suggests a comprehensive strategy on the part of the government to overcome the problem of wastewater-grown vegetables $(W W G V)$.
\end{abstract}

Keywords

Wastewatergrown vegetables, Freshwatergrown vegetables, Contingent valuation method, Quetta, Pesticides JEL Classification N1,N50, Q00, Q2

\section{Introduction}

Water is a basic human need. It is used in different ways, e.g. drinking, domestic and irrigation purposes. The water has been decreasing in quantity and deteriorating in quality, continuously over the past decades. Even though water resources are important for the working of an economy, these are continuously being depleted and damaged at

\footnotetext{
*syed.munawar@buitms.edu.pk
} 
an unsustainable rate (Birol et al., 2006). In this situation, when good-quality water is not available, marginal-quality water_sewage water, industrial wastewater, or any other water that is not fit for drinking is used for irrigation.

Wastewater is used for irrigation in many areas of the world where freshwater is scarce. It (use of wastewater in irrigation) is a common reality in three fourth of Asia, Africa, and Latin America (Gupta et al., 2008). The use of wastewater in agriculture is rising due to water shortage, rise in population, and urbanization which lead to the production of more wastewater in urban areas (Carr et al., 2004). In north and south Africa, ME, South America, southwest America, Southern Europe, Mexico, and a big part of Central and East Asia, at least $20 \mathrm{~m}$ hectares of land is irrigated with wastewater, mostly for vegetables' cultivation (Bigdeli and Seilsepour, 2008). Pakistan is also no exception. Ensink et al. (2004) estimated that $26 \%$ of the total production of vegetables in Pakistan is irrigated with wastewater. Wastewater irrigation is also a common practice in peri-urban and urban areas of Quetta city. A survey result in 2002 shows that $84 \%$ of about 100 farmers farming in and around the city and almost all farmers in the city used wastewater for irrigation, at least in the dry season (Khalil, 2011).

On the other hand, the use of wastewater for irrigation for longer periods may lead to the concentration of heavy metals in soil and plants (Singh et al., 2010). According to (Khan et al. 2008), food crops grown on such soils uptake these heavy metals, which may create a direct threat to human health (Bigdeli and Seilsepour, 2008; Khan et al., 2008; Muchewati et al., 2006; and Singh et al., 2010), when they use these food crops. This contamination of the food chain is one of the key reasons for the toxic pollutants to enter the human body (Khan et al., 2008). On analyzing the quality of municipalwastewater used for canola plants in Quetta city, Kakar et al. (2010) found sulfate, chloride, fluoride, ammonia, cadmium, chromium, lead, mercury, nickel, zinc, barium, iron, manganese, chlorine, calcium, sodium and copper exceeded the limit given by National Environmental Quality Standards (NEQS) for municipal wastewaters of Pakistan.

The health impacts of these metals and toxic pollutants can be chronic and severe. According to Singh et al. (2010), the intake of toxic and contaminated metals through the diet may lead to very serious diseases. Toxicity may cause pulmonary and renal effects in the body (Singh et al., 2010). Exposure to lead $(\mathrm{Pb})$ reduces hemoglobin composition, creates a disturbance in the working of kidneys, joints, reproductive and cardiovascular systems and severely damages the central and peripheral nervous system (Ogweugbu and Muhanga, 2005) and high accumulation of Zink results in weakening of growth and reproduction (Noolan, 1983). Jarup (2003) explained the severe impacts of the constant consumption of contaminated foodstuffs on human organs.

When anything has severe health impacts, it is intuitive for the people to desire and demand its improvement. This motivates researchers to explore and determine the demand for improvements. Many researchers have tried to find out such demands 118 
Journal of Applied Economics and Business Studies, Volume. 4, Issue 4 (2020) 117-134 https://doi.org/10.34260/jaebs.446

through the willingness to pay (WTP) of the consumers of different goods (Boccaletti and Nardella, 2000; Coulibaly et al. 2011; Asim and Lohano, 2015; Bogale and Urgessa, 2012; Lagerkvist et al. 2014). In the same way, when most of the vegetables in Quetta city are irrigated with wastewater, the demand for freshwater-grown vegetables (FWGV) becomes inevitable on the part of the consumers. Therefore, this paper tries to empirically explore the consumers' willingness to pay for freshwater-grown vegetables. For this purpose, a survey based on the contingent valuation method (CVM) and the multiple linear regression (MLR) model is conducted in Quetta at different locations. The researchers' interest in Quetta is mainly for two reasons, first, an ample of research addresses the issue of willingness to pay of the consumers for water-quality improvements (Butt and Khair, 2015) and improved solid-waste management (Khan et al., 2018). However, no work is undertaken yet to estimate the consumers' perception and their demand for fresh and risk-free vegetables in Quetta city. Second, Quetta city is facing a serious water shortage and is declared in the drought-affected areas.

\section{Materials and Methods}

The willingness to pay measurements are based on utility theory and an individual is willing to accept a change if the utility is positive (Coulibaly et al. 2011). In microeconomics theory, following the textbooks' examples (Nicholson, \& Snyder, 2011), an economic model is developed by assuming the utility function of a consumer as:

$$
U=U(Q, Z)
$$

where $Q$ is the quality of vegetables and $Z$ is the set of quantities of other commodities consumed by the consumer. Practically, in applied microeconomics theory, an indirect approach is proposed to be adopted. So, the corresponding indirect utility function is:

$$
V=V(Q, Z, I)
$$

Where " $I$ " represents the disposable income of the household. So, the indirect utility function depends on the quality of vegetables $(Q)$, household disposable income $(I)$, and optimal quantities of other commodities $(Z)$. Both (direct and indirect) methods give the same result, but the indirect approach is much richer in terms of economics it holds (Nicholson and Snyder, 2011). Moreover, indirect utility approaches have been also used and proposed by Chatterjee et al (2017), Mustafa et al. (2014), Asim and Lohano (2015), Khan (2014), and Xie and Zhao (2017). That is why the study uses the indirect utility function. Now suppose, consumers are told that the quality of vegetables will increase from $\mathrm{Q}_{0}$ to $\mathrm{Q}_{1}$ with the presumption that the cost of the FWGV will be higher than the vegetables currently available in the market. Then the consumers must choose whether they are willing to pay more for the FWGV or not. As stated above, the consumers pay only if the utility is positive from the inclusion of $\mathrm{Q}_{1}$ to $\mathrm{Q}_{0}$. In other words, the willingness to pay would be greater than zero when the payment does not decrease the household's overall economic utility. Objectively, it can be said that WTP $>0$ if and 
only if $\mathrm{WTP} \leq \mathrm{Q}_{1}-\mathrm{Q}_{0}$. In indirect utility functions, the income of a household is assumed to be constant. Thus, the willingness to pay can be expressed as:

$$
V\left(Q_{0}, I, Z\right)=V\left(Q_{1}, I-W T P, Z\right)
$$

Where $Q_{0}$ represents the quality of vegetables produced by using wastewater and $Q_{1}$ is the quality of vegetables produced by using fresh water and WTP is the maximum amount of money the consumers would like to pay for FWGV. However, the improved quality of vegetables is represented by a hypothetical scenario in the questionnaire of this paper. The scenario says that water sources used in growing the vegetables are within acceptable levels from the perspective of human health. Moreover, the vegetables are washed properly in the market and are hygienically stored and presented.

\subsection{Estimation of WTP}

For the estimation of willingness to pay function, the specification of an econometric model is necessary. Let's consider that all the individuals face the same improved quality of vegetables $\left(Q_{1}\right)$. Then, WTP variations across respondents depend on the household income $(I)$, the existing quality of the vegetables $\left(Q_{0}\right)$, and other relevant socio-economic characteristics of the respondents. For this purpose, the econometric model used is the multiple linear regression (MLR) model.

$$
W T P_{i}=\alpha+\beta_{i} X_{i}+\varepsilon_{i}
$$

where $X_{i}$ is the vector of independent variables and $\beta_{i}$ is the vector of unknown parameters and this equation (4) is extended in equation (5).

The paper employed a multiple linear regression model to examine whether consumers have positive attitudes towards (are willing to pay for) FWGV and evaluate the factors which affect their willingness to pay for that. When consumers have made their decisions of whether they are willing to pay or not for the FWGV, they were asked: how much you are willing to pay in excess. The answer to this question came in a specified amount which is considered the maximum amount, the consumers are willing to pay. To determine the relationship of these maximum amounts with different explanatory variables, a multiple regression model is used. WTP is the dependent variable in this study. The proposed multiple linear regression (MLR) model takes the form:

$$
\begin{array}{rl}
\text { WTP }_{i}=\alpha+\beta_{1} & E D U_{14-16 Y r s}+\beta_{2} E D U_{16+Y r S}+\beta_{3} A G E+\beta_{4} H H S+\beta_{5} I N C O M E_{L M} \\
& +\beta_{6} I N C O M E_{M}+\beta_{7} I N C O M E_{U M}+\beta_{8} I N C O M E_{H} \\
& +\beta_{9} \text { FWGV_USE } E_{\text {OCCASIONAL }}+\beta_{10} F W G V_{-} U S E_{\text {OFTEN }} \\
& +\beta_{11} \text { AWARENESS } S_{W W I}+\beta_{12} \text { EMP }_{H H H}+\beta_{13} P P_{V E G}+\beta_{14} \text { AREA }+\varepsilon_{i}
\end{array}
$$

Where $\alpha$ is the intercept and $\varepsilon$ is the error term which is normally distributed. The other variables are defined in the following section. 
Journal of Applied Economics and Business Studies, Volume. 4, Issue 4 (2020) 117-134 https://doi.org/10.34260/jaebs.446

\subsection{Data Collection}

For the above econometric model, the dependent variable is a willingness to pay for FWGV. The independent variables included in this paper are education, income, age, household size, respondents' information and perception for wastewater grown (existing quality of) vegetables, their perception of the use of FWGV, employment type of the household head, purchase-place of vegetables and area (town/road). All the variables are explained, one by one by using their short forms. The explanation gives details about how each variable is measured and included in the model of the paper.

Willingness to pay (WTP) refers to the highest amount in Pakistani Rupees (PKR), a consumer is willing to pay to get FWGV. The rupees in addition to a basic price are taken into consideration in this paper. Willingness to pay was measured separately for three types of vegetables, namely: cauliflowers/cabbages, spinaches, and salads. Education refers to the educational levels of the respondents. For the analysis, this variable was divided into three categories with intermediate level (EDU $\mathrm{LOW}_{\text {) }}$, 14-16 years $\left(E_{14} U_{16 \mathrm{Yrs}}\right)$, and higher than 16 years $\left(\mathrm{EDU}_{16+\mathrm{Yrs}}\right)$ and set EDU $\mathrm{LOW}_{\text {as }}$ the reference category. The age of the respondents is measured in years and men above 18 years of age were considered. Household size (HHS) represents a number of family members living in one house and sharing the same kitchen. Income refers to a total household monthly income of the respondent in PKR and it is taken as a categorical variable and recorded in five groups. The first group consists of the respondents (INCOME I $_{\text {) with incomes of less than PKR 20,000, the second group (INCOME }}$ ) of PKR 20,000-40,000, the third group (INCOME ${ }_{M}$ ) of PKR 40,000-80,000, the fourth group (INCOME $\mathrm{IM}_{\mathrm{M}}$ ) of PKR 80,000-150,000 and the fifth income group (INCOME of PKR 150,000 and above. The first group, $\mathrm{INCOME}_{\mathrm{L}}$, is kept as the reference category. Freshwater-Grown Vegetables' Use (FWGV_USE) shows the respondents' answers about how much they have been using FWGV before this survey. Three dummy variables have been created. The first category (FWGV_USERARE) is not included in the model and is kept as the reference category. The other two categories are FWGV_USEOCCASIONAL and FWGV_USEOFTEN. Awareness about Wastewater-Grown

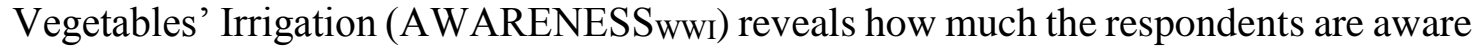
of the wastewater irrigation of vegetables in Quetta city. It is also included as a categorical variable. Two options were included in the questionnaire to know the awareness of the respondents about wastewater-grown vegetables (WWGV) in Quetta city and for it the dummy variable, ' 0 ' shows that the respondent knows nothing or a little about the wastewater irrigation of vegetables and ' 1 ' denotes that he has a fair amount of knowledge or a great deal of knowledge and awareness about the wastewater irrigation of vegetables. Employment or Occupation of the Household Head (EMP $\left.\mathrm{HHH}_{\mathrm{H}}\right)$ is measured as a dummy variable where ' 1 ' $=\mathrm{EMP}_{\mathrm{HHH}}$ is a government employee or has his own business and ' 0 ' $=\mathrm{EMP}_{\mathrm{HHH}}$ has any other type of employment. Purchase-Place of the Vegetables ( $\mathrm{PP}_{\mathrm{VEG}}$ ) refers to the place where vegetables are mostly bought by the respondent and his family. It is also measured as a dummy variable where ' 1 ' shows that 
the respondent buys vegetables from convenience shops and ' 0 ' denotes that he makes purchases from any other place. AREA refers to the area of the respondent. It is included as a dummy variable. It is ' 1 ' if the respondent belongs to the site where vegetables are mostly grown by using wastewater (Brewery Road in this case) and ' 0 ' otherwise.

\subsection{Description of Study Area}

Quetta is the largest city and the capital of Balochistan and covers an area of $2653 \mathrm{~km}^{2}$ with a total population of 2,275,699 people and a total number of households are 276,711 of which 148,093 are residing in rural areas and 128,618 are residing in urban areas (Population Census, 2017).

According to the Development Statistics of Balochistan 2015-16, different kinds of vegetables are produced in Quetta. These are ladyfinger, tinda, radish, spinach, turnip, broad bean, cabbage, carrot, gourds, pumpkin, cauliflower, beetroot, brinjal, lufa, cucumber, etc. In these vegetables, cauliflower, cabbage, spinach, and leafy salads are produced on a bigger stage by using wastewater in the city. The area selected for this paper is Quetta city and the data is collected from 5 different sites.

Data was collected through convenience sampling techniques with the following two stages. At the first stage, five sub-areas in the city were chosen. Then, different sites were selected in each of these sub-areas. In the end, data were collected from the consumers who buy vegetables for their household kitchen. The respondents were approached personally, and their responses were recorded face-to-face via questionnaires. Only people above 18 years of age were considered on the assumption that children and under-age would not be able to understand the aims of the research and the questions included in the questionnaire.

In a total of 260 individuals were talked to for their opinions. The answers of the 255 individuals were recorded and analyzed in the paper. The 5 of the remaining questionnaires were not included in the sample because of having responses considered as incomplete or outliers. The area-wise distribution of the sample is as follows: Saryab Road 53; Brewery Road 51; Samungli Road 50; Kasi Road 51; and Alamdar Road 50. The number of respondents in each area is listed (Table 1).

Table 1: Number of Respondents Interviewed Area Wise

\begin{tabular}{lcccccc}
\hline Name of Area & $\begin{array}{c}\text { Saryab } \\
\text { Road }\end{array}$ & $\begin{array}{c}\text { Brewery } \\
\text { Road }\end{array}$ & $\begin{array}{c}\text { Samungli } \\
\text { Road }\end{array}$ & $\begin{array}{c}\text { Kasi } \\
\text { Road }\end{array}$ & $\begin{array}{c}\text { Mari } \\
\text { Abad }\end{array}$ & TOTAL \\
\hline No of Respondents & 53 & 51 & 50 & 51 & 50 & 255 \\
\hline Source: Authors' Survey, 2018 & & & & &
\end{tabular}

\subsection{Questionnaire}

The data were collected through a semi-structured questionnaire. The questionnaire was made gone through the stages of both the pre-testing and pilot survey. A hypothetical bias which sometimes happens in some contingent valuation method (CVM) studies, is not likely to happen here as most of the respondents are familiar with 
the service in question. On the other hand, the format in which the WTP question is stated is the main factor that affects the outcome of CVM surveys (Oerlemans et al., 2016). To avoid these all, an introductory paragraph was added in the beginning so that the respondents could understand the goals of the study and feel comfortable to answer the questions. Moreover, each question was also translated into Urdu to make it easy for the respondents to understand the questions. The literature in determining consumers' willingness to pay for various service improvements as Chatterjee et al., (2017); Xie and Zhao, (2017); Carlsson and Johansson, (2000); Mustafa et al. (2014); Asim and Lohano (2015); Khan (2014); Coulibaly et al., (2011); Boccaletti and Nardella, (2000); and Yahaya, (2008) are consulted in designing the questionnaire for this study. The popular methods for recording the answers of the respondents are open-ended questions, bidding games, dichotomous choice, payment cards, and others (Frew et al., 2003). However, in this paper, both price bids and open-ended questions were used. Open-ended techniques give a point estimate of the interviewee's maximum WTP (Frew et al., 2003; Chatterjee et al., 2017).

\section{Results and Discussions}

The results include estimations about the socioeconomic characteristics, perception, and awareness, and consumers' willingness to pay for FWGV in Quetta. The results are based on the data of 255 respondents through the questionnaires collected in the field survey in May-June 2018. The results of socioeconomic characteristics of education, income levels, and occupations of the household heads are given in Table 2. In education, most of the respondents $(51 \%)$ are found to have between 14 and 16 years of education. Among the others, $8 \%$ of the respondents had no/primary education, $8 \%$ had an education level of 18 years or above, and $33 \%$ of the respondents had education levels of matric/intermediate.

The results show that most of the respondents $(60 \%)$ have incomes between Rs. 20,000 and Rs. 80,000 . While $14 \%$ of the respondents have an income of less than Rs. $20,000 /-$ and $10 \%$ have above than Rs. $150,000 /-, 27 \%$ of the respondents have incomes between Rs. 20,000 to 40,000/-, 33\% have income between Rs. 40,000 to 80,000/- and $16 \%$ between Rs. 80,000 to 150,000 . Employment categories data show, $64 \%$ of the household heads are government employees or having their businesses and $36 \%$ had other types of employment. The results of the survey regarding education, income, and employment are given in Table- 2 .

Table 2: Socioeconomic Characteristics of the Sampled Respondents

\begin{tabular}{|l|l|l|l|}
\hline \multicolumn{1}{|c|}{ Variables } & \multicolumn{1}{|c|}{ Options } & Percentages & Frequency \\
\hline \multirow{5}{*}{ Educational levels } & 1. No Education/Primary & $8 \%$ & 20 \\
\cline { 2 - 4 } & 2. Matric/Intermediate & $33 \%$ & 83 \\
\cline { 2 - 4 } & 3.14 Yrs. to 16 Yrs. & $51 \%$ & 131 \\
\cline { 2 - 4 } & 4.18 Yrs. or above & $8 \%$ & 21 \\
\cline { 2 - 4 } & Total & $100 \%$ & 255 \\
\hline Monthly HH Income & 1. Less than RS. 20,000/- & $14 \%$ & 37 \\
\hline
\end{tabular}


Salah Udin Buzdar, Syed Muhammad Khair and Syed Munawar Shah

\begin{tabular}{|c|c|c|c|}
\hline & 2. RS. 20,000-Rs. 40,000 & $27 \%$ & 68 \\
\hline & 3. RS. 40,000-Rs. 80,000 & $33 \%$ & 83 \\
\hline & 4. RS. 80,000 -Rs. 150,000 & $16 \%$ & 41 \\
\hline & 5. RS. 150,000 and above & $10 \%$ & 26 \\
\hline & Total & $100 \%$ & 255 \\
\hline \multirow{3}{*}{ Occupation of HH Head } & 1. Salaried Worker/Own Business & $64 \%$ & 164 \\
\hline & $\begin{array}{l}\text { 2. Other Types of Employment (unemployed, } \\
\text { street vendor/ small informal business, } \\
\text { private employee, and others) }\end{array}$ & $36 \%$ & 91 \\
\hline & Total & $100 \%$ & 255 \\
\hline
\end{tabular}

Source: Authors' Survey, 2018

The mean age of the respondents was found to be 30.8 years and the standard deviation is 10.3 years. The minimum age was 18 years and the maximum age was 65 years. The higher mean age is because children were not included in the survey. The mean household size was almost 10 persons and the standard deviation was 4.27 . The minimum household size was 2 persons and the maximum number of persons living in a household was found 24 in the survey. Further explanation of age and household size is given in Table 3.

\section{Table 3: Sample Averages of Age and Household Size}

\begin{tabular}{lcc}
\hline Options & Age (Yrs.) & HH Size \\
\hline Mean & 30.76 & 10 \\
S.D. & 10.2759 & 4.27 \\
Min Value & 18 & 2 \\
Max Value & 65 & 24 \\
\hline
\end{tabular}

Source: Authors' Survey, 2018

\subsection{Consumer's ranking of the Food Items Based on Usage}

Figure-1 shows the results of the rankings of the main food items from the respondents.

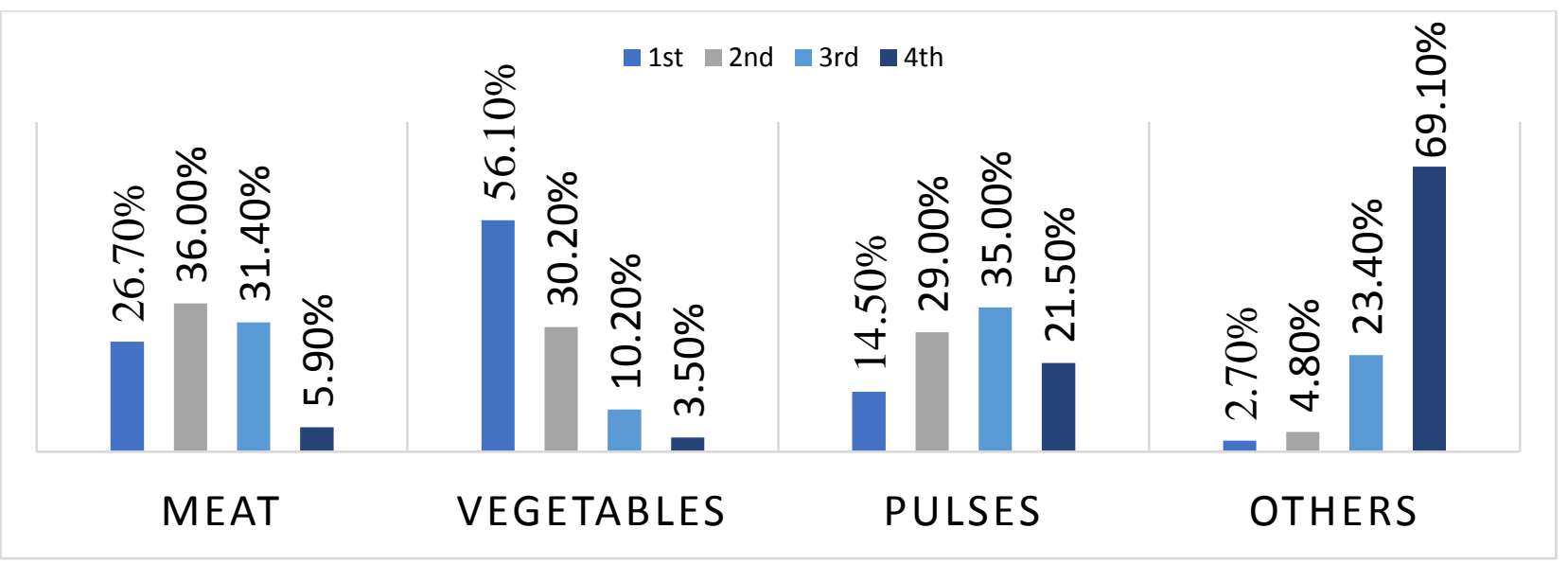

Figure 1: Consumers' Ranking of the Food Items According to Their Usage Source: Authors' Survey, 2018 
Journal of Applied Economics and Business Studies, Volume. 4, Issue 4 (2020) 117-134 https://doi.org/10.34260/jaebs.446

In the survey, some $56 \%$ of the respondents ranked vegetables as their main food item, $30 \%$ ranked vegetables at $2^{\text {nd }}, 10 \%$ ranked vegetables at $3^{\text {rd }}$ and $3.5 \%$ ranked vegetables at $4^{\text {th }}$ in their preferences in food items consumptions. The meat usage preferences are shown by $26.7 \%$ of the households, pulses preferences are shown by $14.5 \%$ of the respondents in the survey (Figure 1). and others $2.7 \%$.

\subsection{Purchase-Place of Vegetables}

The respondents were asked in the survey about their usual and regular buying-place of vegetables. Some $52 \%$ of the respondents buy vegetables from convenience shops, followed by $24 \%$ in vegetable markets, $23 \%$ in particular-shops, and only $1 \%$ from farm places. The high percentage of respondents buying vegetables from convenience shops might be because there is no well-established vegetable market in Quetta. Moreover, the prices of vegetables are generally high in established shops as compared to roadside sellers. The results are shown in figure- 2 .

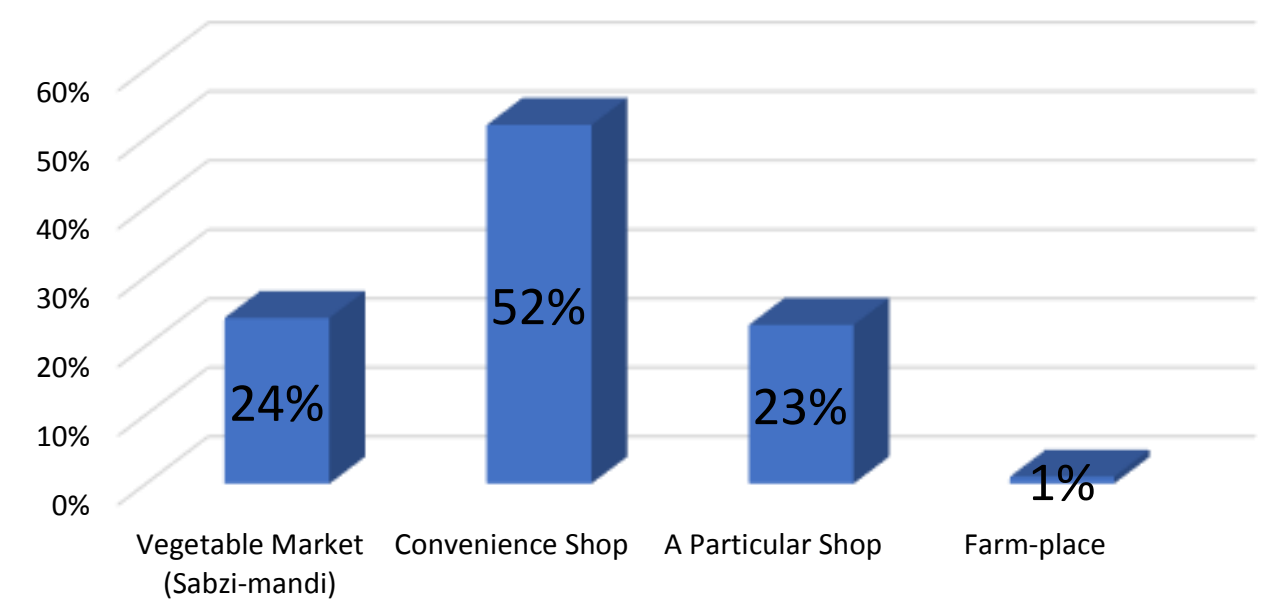

Figure 2: Purchase-Place of Vegetables

Source: Authors' Survey, 2018

\subsection{Diseases Recorded in Last One Year in the Families of the Respondents}

As it is clear from Singh et al., (2010), Ogweugbu and Muhanga, (2005), Noolan, (1983) Bluementhal and Peasy (2002) that WWGV cause diarrhea, kidney, and lungs related diseases, cancer, weakening of growth in children and deficiency of blood. The survey results show diarrhea as the most frequent disease faced by the families of the respondents and $50 \%$ of the respondents had cases of this disease in their families followed by $35 \%$ of the respondents who reported kidneys-related diseases and $32 \%$ of the respondents have a report of weak growth in children. Among others, $25 \%$ of the respondents stated lung-related diseases and $24 \%$ deficiency of blood in their family members in the last year (Figure 3). Cancer was found in only $7 \%$ of the households in the survey. However, there are certainly many other factors that cause these diseases. 
That's why it is difficult to separate the role which WWGV plays in causing these diseases.

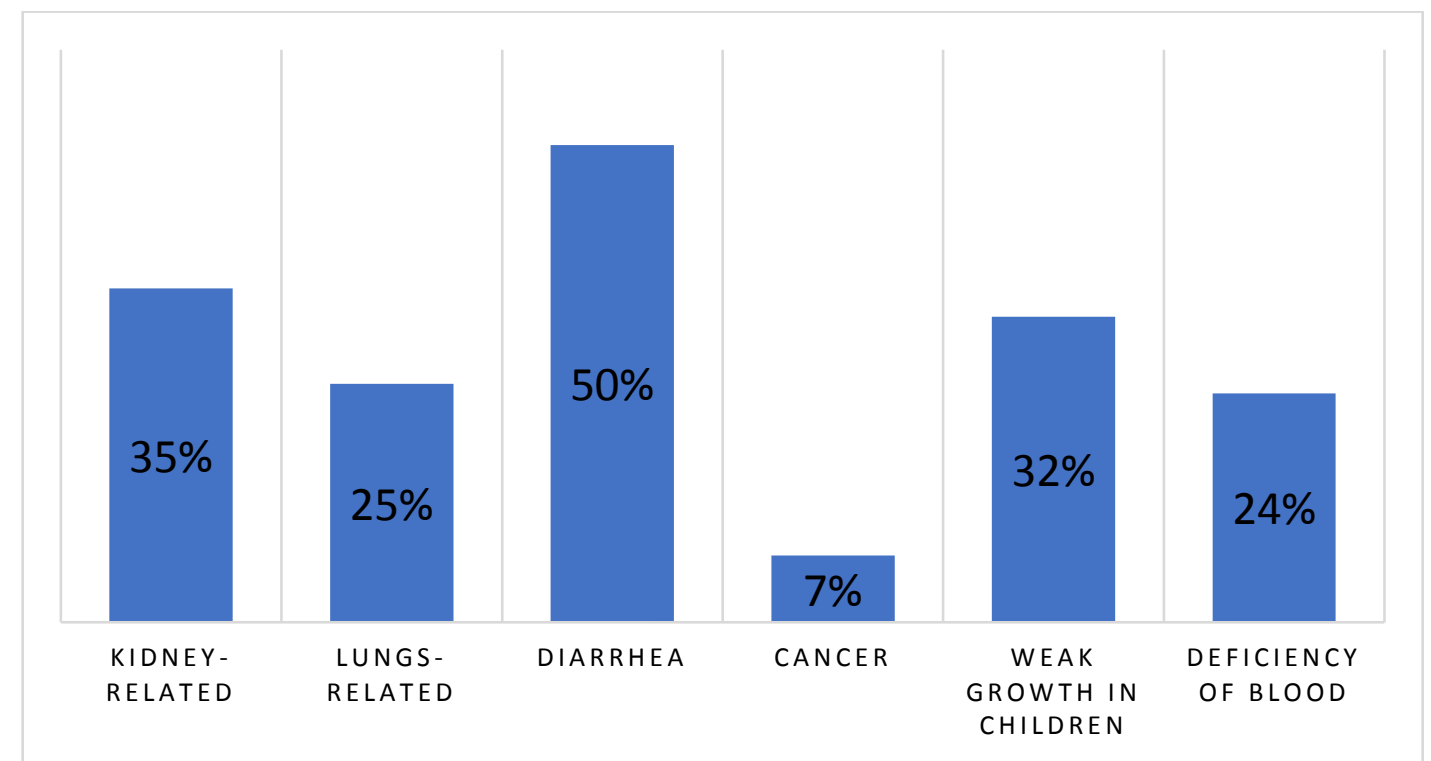

Figure 3: Diseases Recorded in Last One Year in the Families of the Respondents Source: Authors' Survey, 2018

3.4 Perception and Awareness

Awareness about Wastewater-Grown Vegetables (WWGV)

The survey results revealed that most of the respondents were very much aware of the health hazards and negative impacts of the WWGV in Quetta city. When they were asked as to how much they saw, heard, or read about WWGV in the City, the data show that $21 \%$ of the respondents have a great deal of knowledge about WWGV while $56 \%$ have a fair amount of information, $20 \%$ has a little information and only $3 \%$ of the respondents know nothing about the wastewater irrigation in vegetables' production (Table 4).

\section{Table 4: Awareness about Wastewater-Grown Vegetables in Quetta}

\begin{tabular}{lll}
\hline Options & Percentages & Frequencies \\
\hline Nothing & $3 \%$ & 7 \\
A Little & $20 \%$ & 52 \\
A Fair Amount & $56 \%$ & 142 \\
A Great Deal & $21 \%$ & 54 \\
\hline Total & $100 \%$ & $\mathbf{2 5 5}$ \\
\hline
\end{tabular}

Source: Authors' Survey, 2018

Freshwater-Grown Vegetables (FWGV)'s Use of the Respondents

The respondents were asked about how often they have been using freshwater-grown cauliflowers, spinaches, or salads before this survey to empirically know the perception of the consumers regarding the current state of vegetables. The data show that only $4 \%$ 
Journal of Applied Economics and Business Studies, Volume. 4, Issue 4 (2020) 117-134 https://doi.org/10.34260/jaebs.446

of the respondents stated that they always use the three types of FWGV, $36 \%$ of the respondents often use three types of FWGV of such vegetables, $50 \%$ of the consumers revealed that they have been occasionally using freshwater-grown cauliflowers, spinaches or salads, and $10 \%$ of the respondents have disclosed that they have been rarely using these three types of FWGV (Table 5). The results show that most of the consumers know or at least think that the vegetables they are using are not grown in freshwater. But they still use such vegetables because they are left with no option other than this.

Table 5: Freshwater-Grown Cauliflowers, Spinaches and Salads Use of the Respondents

\begin{tabular}{lcc}
\hline Options & Percentages & Frequencies \\
\hline Rarely & $10 \%$ & 26 \\
Occasionally & $50 \%$ & 128 \\
Often & $36 \%$ & 92 \\
Always & $4 \%$ & 9 \\
\hline Total & $\mathbf{1 0 0} \%$ & $\mathbf{2 5 5}$ \\
\hline
\end{tabular}

Source: Authors' Survey, 2018

\subsection{Consumers' WTP}

The results reveal that consumers are willing to pay for freshwater-grown and healthy vegetables. Out of a total of 255 respondents, 222 respondents $(87 \%)$ are found willing to pay extra for cauliflowers and spinaches each, and 224 representing $(88 \%)$ of the respondents for salads only. They were ready to pay extra amounts to enjoy FWGV. On the other hand, only $13 \%$ and $12 \%$ of the respondents responded that they are not ready to pay any extra amount for these vegetables, respectively. The reasons for not paying an extra amount for FWGV are shown in the table $6,15 \%$ of the respondents said that they are satisfied with whatever existing state of vegetables, and $6 \%$ of the respondents said that they did not use FWGV vegetables. On the other hand, 58\% of the respondents expressed that they could not afford to pay any extra for FWGV and $21 \%$ of them said they just do not want to pay extra for FWGV (Table 6).

Table 6: Reasons for Non-Willingness to Pay

\begin{tabular}{lcc}
\hline Options & Frequency & Percentages \\
\hline Satisfied with the Existing State of Vegetables & 5 & $15 \%$ \\
Cannot Afford & 19 & $58 \%$ \\
Do not want to Pay & 7 & $21 \%$ \\
Do not use these Vegetables & 2 & $6 \%$
\end{tabular}

Source: Authors' Survey, 2018

In the Table-7, the responses of those who were willing to pay extra for FWGV are described. The respondents were willing to pay an extra amount of PKR. 13.71 on the average for cauliflowers/cabbages over the basic price. In this way, the mean WTP for spinaches, and salads were shown about PKR. 13 and PKR. 17, respectively. The standard deviation was found to be $8.48,7.91$, and 10.2 for cauliflowers, spinaches, and salads, respectively. The maximum value for WTP was found to be PKR. 35 for 
cauliflower and spinaches each, and PKR. 45 for salads. Skewness was found to be $\leq 10 \%$ (less than $10 \%$ ) in WTPs of all the vegetables.

On analysis, the results in Table-7 show that salads are the most used form of vegetable. FWGV of salad got the highest average extra bid price (i.e. PKR 17 extra on its unit price of PKR 40) and the least number of non-responses and the highest individual payment amount. In other words, the consumers are willing to pay $43 \%$ more of the basic price if FWG salad is made available to them. Similarly, the average extra amount of PKR. 13.71 and PKR. 13 on each kilogram and bundle for cauliflowers and spinaches, respectively, are shown in data and the results prove that consumers are ready to purchase FWGV if prices are higher than the non-FWGV for consumption (Table 7).

Table 7: Descriptive Statistics of the WTP for Different Vegetables in PKRs

\begin{tabular}{|c|c|c|c|}
\hline Options & WTP for Cauliflower/Cabbage & WTP for Spinach & WTP for Salad \\
\hline Average & 13.71 & 12.94 & 16.84 \\
\hline S.D. & 8.48 & 7.91 & 10.20 \\
\hline Max Value & 35 & 35 & 45 \\
\hline Min Value & 0 & 0 & 0 \\
\hline Skewness ${ }^{(a)}$ & 0.075 & 0.104 & 0.049 \\
\hline
\end{tabular}

(a): the value of skewness lies between 0 and 1 .

Source: Authors' Survey, 2018

\subsection{Factors Affecting Consumers' WTP for Freshwater-Grown Vegetables}

The estimates of the parameters for the WTP of the consumers on different socioeconomic and other factors were acquired by estimating the multiple linear regression (MLR) model specified in equation 5. The results were obtained to know the impact of different factors (independent variables) on the consumers' willingness to pay for FWGV (dependent variable). The results were obtained separately for each of the three vegetable types and are given in Table- 8 . Before going for the analysis, some diagnostic tests were performed and most of the tests' statistics (Jarque-Bera test, Shapiro-Wilk W test, Ramsey Reset test, Breusch-Pagan/Cook-Weisberg Test, and VIF) confirm the usage of MLR for estimating the parameters of the interest of this study. The results of the paper show that higher levels of education, all categories of income, FWGV's use, awareness about WWGV's irrigation, and the employment of householdhead have significant effects on the consumers' WTP for FWGV, and education levels of less than 16 years and area were found insignificant for all the three types of FWGV vegetables. Respondents' age, household size, and purchase-place of the vegetables were found significant in the case of salads and insignificant in the case of cauliflowers and spinaches. In the first model given in Table- 8 where the dependent variable is WTP for cauliflowers, the $\mathrm{R}^{2}$ is $67.70 \%$ and the Adjusted $\mathrm{R}^{2}$ is $65.82 \%$. In the second model where, the dependent variable is WTP for Spinach, the $\mathrm{R}^{2}$ and the Adjusted $\mathrm{R}^{2}$ of the model are $67.90 \%$ and $66.03 \%$, respectively. In the third and final model, the dependent variable is WTP for Salad. The $\mathrm{R}^{2}$ is $74.75 \%$ and the Adjusted $\mathrm{R}^{2}$ is $73.28 \%$. These values for $\mathrm{R}^{2}$ and Adjusted $\mathrm{R}^{2}$ show that all the independent variables are combinedly 
Journal of Applied Economics and Business Studies, Volume. 4, Issue 4 (2020) 117-134 https://doi.org/10.34260/jaebs.446 able to explain significant portions of the variations in the dependent variables (WTP for cauliflower, spinach and salad). The F-statistics of 35.94, 36.27 and 50.75 for the three models are also satisfactory. Moreover, all the F-statistics are significant at $1 \%$ which assures the overall significance of the models by rejecting the hypothesis that the coefficients of all the independent variables are zero (Table 8).

\subsection{Discussion on the estimated parameters of MLR}

There is a positive relationship found between WTP and education levels. WTP increases as the level of education increases. On average, the consumers with the EDU 14 16 Yrs and above are willing to pay extra/more amounts for FWGV as compared to the EDULOw for all the three types of FWG vegetables, with the exception that consumers with EDU 14-16Yrs are insignificant in all the three FWG vegetables models. This positive relationship of education with the willingness to pay is in line with other studies. As, Mustafa et al (2014) mention that people having some level of education are willing to pay about $25 \%$ more than those who have no or less education. Similarly, respondents with high levels of education have a higher WTP (Chatterjee et al., 2017; and Coulibaly et al. 2011).

Age was found to be insignificant in the case of cauliflowers and spinaches while the significant in case of salads. Its coefficients range from -0.02 to -0.06. It is also affecting the willingness to pay inversely against the expected positive relationship. The negative coefficients show that younger people are more cautious about their health than older people. But, it is still in accordance with some studies. The relationship of age with WTP was reported differently in the literature. Age was found significant and negative by Xie and Zhao (2017) and Chatterjee et al. (2017) but insignificant and positive by Boccaletti and Nardella, (2000).

Household size has a negative coefficient, as expected before the survey, for all the vegetables and is insignificant in cauliflowers and spinaches but significant in salads. Its coefficients go from -0.1 to -0.14 . The negative sign shows that large households are willing to pay less amount than small households. This can be attributed to the fact that larger households are likely to have low per head incomes and, also, their consuming quantities are higher and, hence, have to pay bigger portions of their incomes. The results are in line with the studies of Xie and Zhao (2017) and Coulibaly et al. (2011).

Income was found one of the most effective explanatory variables in this study. Respondents with the level of monthly household incomes between PKRs 20,000 and

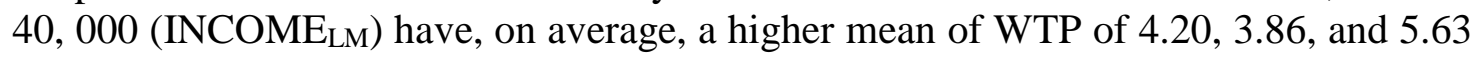
for cauliflowers, spinaches, and salads, respectively, as compared to those who have monthly incomes of less than PKR 20,000 (lowest income group). The difference grows larger with an increase in income groups. The respondents in the category of the $\mathrm{INCOME}_{\mathrm{H}}$ are, on average, shown willing to pay PKRs 18.55, 17.20, and 24.35 more than the reference category (i.e. lowest income group) for cauliflowers, spinaches, and 
salads, respectively. The positive coefficients of income indicate that consumers with higher incomes are willing to pay more amount than those who have lower incomes. The reason for higher WTP from high-income groups confirms the affordability hypothesis that they can afford to pay more. The results are also in accordance with the hypothesized relationship between income and willingness to pay. The results confirm the results of the studies of Boccaletti and Nardella (2000), Mustafa et al. (2014), Xie and Zhao (2017), Carson and Mitchell (1993), and Asim and Lohano (2015) for showing a positive relationship between income and WTP.

The categories of freshwater-grown vegetables (FWGV)'s use has negative coefficients which are significant at $1 \%$ for the WTP of all the three vegetables. FWGV_USERARE was kept as the reference category. The negative coefficients of the other two categories (FWGV_USEOCCASIONAL and FWGV_USE ${ }_{\text {OFTEN }}$ ) show that if a respondent is already using (or he thinks that he is using) FWG vegetables, then he pays the normal price and may not be liable to pay an extra amount. The more he is already using FWGV, the less he is likely to pay an extra amount for FWGV. If he rarely uses such FWG vegetables, he would be ready to pay more to get these vegetables and if he is always using such vegetables, he would be willing to pay no or less amount for such FWG vegetables. In this case (say), he is already safe from the negative impacts of wastewater-grown vegetables, and hence, no need to pay more. No use of this variable was found in the literature. It was included in the model after testing it in the pilot study, and the results are in accordance with the variables' hypothesized inverse relationship with willingness to pay.

The awareness about wastewater-grown vegetables (WWGV) is the other most important factor after income affecting the willingness to pay of the consumers. The awareness and knowledge about WWGV were hypothesized to be positively affecting the consumers' willingness to pay. It is highly significant and has positive coefficients of 4.52 in cauliflower, 4.17 in spinaches, and 6.03 in salads. The consumers who had a great deal of knowledge about WWGV were willing to pay more while those who know nothing or have little knowledge were willing to pay less. The consumers with greater knowledge and awareness are aware of the negative impacts of WWGV. They are likely to pay more because they think that the opportunity cost of negative impacts is higher than the amount they pay for freshwater-grown vegetables. The results of the paper are in line with Coulibaly et al. (2011) and Boccaletti and Nardella (2000).

The employment categories of household heads showed a positive coefficient of 2.20 in cauliflower, 1.62 in spinach, and 2.18 in salads and are significant at $1 \%$ in cauliflower and salads and 5\% in spinach. It implies that government employees or business owner is willing to pay more than those who have any other type of employment. Job security attributes of government employee and higher-income earning expectations of a business owner may prompt consumers to pay extra for FWG vegetables in Quetta city. On the contrary to that, household heads who are unemployed or having an insecure job 
as a private employee, and unskilled labor on daily wages tend to pay less for FWG vegetables as their income echelons could not afford extra payment for FWGV in Quetta city. The results are in line with the results of Yahaya (2008).

The other two variables included in the model as explanatory variables are the purchase place of the vegetables and the residence of the respondents. Purchase-place of vegetables is only significant in salads, at $10 \%$, and insignificant in the other two vegetables. The results of residence of the respondents are found insignificant in all the three-vegetable-based MLR models (Table 8).

Table 8: Results of the Parameter Estimates for the WTP of Freshwater-Grown Vegetables

\begin{tabular}{|c|c|c|c|c|c|c|}
\hline \multirow[t]{2}{*}{ Variable Names } & \multicolumn{2}{|c|}{ Cauliflower } & \multicolumn{2}{|c|}{ Spinach } & \multicolumn{2}{|c|}{ Salad } \\
\hline & Coefficient & $\mathrm{t}(\mathrm{P}>|\mathrm{t}|)$ & Coefficient & $\mathrm{t}(\mathrm{P}>|\mathrm{t}|)$ & Coefficient & $\mathrm{t}(\mathrm{P}>|\mathrm{t}|)$ \\
\hline $\mathrm{EDU}_{14-16 \mathrm{Yrs}}$ & 1.12 & $1.57(.117)$ & 0.94 & $1.41(.160)$ & 1.08 & $1.42(.157)$ \\
\hline $\mathrm{EDU}_{16+\mathrm{Yrs}}$ & $3.70 * * *$ & $2.83(.005)$ & $4.37 * * *$ & $3.61(.000)$ & $5.64 * * *$ & $4.07(.000)$ \\
\hline $\mathrm{AGE}$ & -0.04 & $-1.06(.291)$ & -0.02 & $-0.61(.542)$ & $-0.06 *$ & $-1.76(.08)$ \\
\hline HHS & -0.10 & $-1.17(.243)$ & -0.10 & $-1.35(.179)$ & $-0.14 *$ & $-1.71(.088)$ \\
\hline INCOMELM $_{L M}$ & $4.20 * * *$ & $3.98(.000)$ & $3.86 * * *$ & $3.93(.000)$ & $5.63 * * *$ & $5.01(.000)$ \\
\hline $\mathrm{INCOME}_{\mathrm{M}}$ & $9.43 * * *$ & $8.57(.000)$ & $8.96 * * *$ & $8.77(.000)$ & $12.55 * * *$ & $10.73(.000)$ \\
\hline INCOMEUM & $13.50 * * *$ & $10.31(.000)$ & $12.83 * * *$ & $10.55(.000)$ & $17.25 * * *$ & $12.4(.000)$ \\
\hline $\mathrm{INCOMEH}_{\mathrm{H}}$ & $18.55 * * *$ & $12.57(.000)$ & $17.20 * * *$ & $12.52(.000)$ & $24.35 * * *$ & $15.51(.000)$ \\
\hline FWGV_USEOCCASIONAL & $-3.65 * * *$ & $-3.32(.001)$ & $-2.92 * * *$ & $-2.86(.005)$ & $-3.60 * * *$ & $-3.08(.002)$ \\
\hline FWGV_USEOFTEN & $-4.76 * * *$ & $-3.86(.000)$ & $-3.90 * * *$ & $3.40(.001)$ & $-4.68 * * *$ & $-3.58(.000)$ \\
\hline AWARENESSWWI & $4.52 * * *$ & $4.82(.000)$ & 4.17 & $4.78(.000)$ & $6.03 * * *$ & $6.04(.000)$ \\
\hline $\mathrm{EMP}_{\mathrm{HHH}}$ & $2.20 * * *$ & $2.97(.003)$ & $1.62 * *$ & $2.36(.019)$ & $2.18 * * *$ & $2.78(.006)$ \\
\hline$P_{\text {VEG }}$ & 0.60 & $0.9(.371)$ & 0.93 & $1.51(.132)$ & $1.46 * *$ & $2.08(.039)$ \\
\hline AREA & -0.46 & $-0.58(.565)$ & -0.95 & $-1.29(.199)$ & -1.25 & $-1.48(.14)$ \\
\hline CONSTANT & $5.20 * * *$ & $2.67(.008)$ & $4.37 * *$ & $2.42(.016)$ & $5.44 * * *$ & $2.63(.009)$ \\
\hline $\mathrm{R}^{2}$ & $67.70 \%$ & & $\mathrm{R}^{2}$ & $67.90 \%$ & $\mathrm{R}^{2}$ & $74.75 \%$ \\
\hline Adjusted $\mathrm{R}^{2}$ & $65.82 \%$ & & Adjusted $\mathrm{R}^{2}$ & $66.03 \%$ & Adjusted $\mathrm{R}^{2}$ & $73.28 \%$ \\
\hline $\mathrm{F}(14,240)$ & 35.94 & & $\mathrm{~F}(14,240)$ & 36.27 & $\mathrm{~F}(14,240)$ & 50.75 \\
\hline Prob. $>\mathrm{F}$ & $0.000 * * *$ & & Prob. $>\mathrm{F}$ & $0.000 * * *$ & Prob. $>\mathrm{F}$ & $0.000 * * *$ \\
\hline No. of Observations & 255 & & - & - & - & - \\
\hline
\end{tabular}

* significant at $10 \%$, ** significant at $5 \%$, and $* * *$ significant at $1 \%$ and () shows $p$-values

Source: Authors' Survey, 2018

\section{Conclusions}

To get safe food is getting wide importance in the lives of consumers and many producers have tried to consider the supply of such vegetables in the market. The paper used a survey-based contingent valuation method (CVM) to record the amounts respondents were willing to pay in addition to the original price of the vegetables available in the market to-date. MLR model is used to estimate the factors which affect the WTP for FWGV in Quetta city. Vegetables, being the most used food item among the consumers in Quetta city, are associated with many factors of health, income, employment, freshness, grown with freshwater or wastewater, and another factor to give perceptions and preferences for its WTP. It is shown that consumers are aware of both vegetables grown by fresh and wastewater in Quetta city. Consumers with higher levels of information about the hazards of WWGV, more awareness, higher education levels, 
more earnings and income levels, and younger are more likely to pay an extra amount than the market price for the FWGV in Quetta city. While, consumers with lower levels of education, knowing less about the probable health damages of WWGV, less awareness, lower levels of income, and having unskilled jobs or non-governmental jobs on contracts are less likely to pay extra amount for FWGV in Quetta city. Among the vegetable types of this study, salad has been given more considerations by the explanatory factors of education, age, income, employment categories of government employment, and own businesses as compared to the other two types of vegetables in Quetta city.

Moreover, the results show that consumers have a high demand for FWGV as depicted by their WTP responses. These high demands have great importance for the producers and policymakers. Considering this high demand, the city and provincial governments should encourage the production of such vegetables through public awareness campaigns, media, and moral suasion. The government should also look at the quality of the wastewater being used in irrigation under the supervision of biological, chemical, and medical experts and economists. Only, in this way, she would be able to know the health hazards related to wastewater-grown vegetables. Farmers and vegetable growers should use different treatment options for the wastewater before finally using it for irrigation. The high demand is also a sign of investment opportunities in the production of such vegetables. Private or public-sector organizations should start this as a test in the beginning and go forward with a plan. For such policies to be successful, different price options should be tested as the prices might be higher than the current market prices. Certificates should be given to both the vegetable producers and sellers who produce and sell freshwater-grown vegetables by the city government so that the consumers could differentiate between wastewater-grown and freshwater-grown vegetables.

\section{References}

Asim, S., Lohano, H. D., \& Ahmad, I. (2015). Households' Willingness to Pay for Improved Tap Water Services in Karachi, Pakistan/Comments. Pakistan Development Review, 54(4), 507.

Bigdeli, M., \& Seilsepour, M. (2008). Investigation of metals accumulation in some vegetables irrigated with waste water in Shahre Rey-Iran and toxicological implications. In American Eurasian J. Agric. Environ. Sci.

Birol, E., Karousakis, K., \& Koundouri, P. (2006). Using economic valuation techniques to inform water resources management: A survey and critical appraisal of available techniques and an application. Science of the total environment, 365(1), 105-122.

Blumenthal, U. J., \& Peasey, A. (2002). Critical review of epidemiological evidence of the health effects of wastewater and excreta use in agriculture. unpublished 
Journal of Applied Economics and Business Studies, Volume. 4, Issue 4 (2020) 117-134 https://doi.org/10.34260/jaebs.446 document prepared for World Health Organization, Geneva, www. who. int/water_sanitation_health/wastewater/whocriticalrev. pdf.

Boccaletti, S., \& Nardella, M. (2000). Consumer willingness to pay for pesticide-free fresh fruit and vegetables in Italy. The International Food and Agribusiness Management Review, 3(3), 297-310.

Bogale, A., \& Urgessa, B. (2012). Households' willingness to pay for improved rural water service provision: application of contingent valuation method in Eastern Ethiopia. Journal of Human Ecology, 38(2), 145-154.

Butt, M., \& Khair, S. M. (2016). Cost of illness of water-borne diseases and willingness to pay for quality water: a case study of Quetta. BUITEMS, Unpublished Thesis

Carlsson, F., \& Johansson-Stenman, O. (2000). Willingness to pay for improved air quality in Sweden. Applied Economics, 32(6), 661-669.

Carr, R. M., Blumenthal, U. J., \& Mara, D. D. (2004). Guidelines for the safe use of wastewater in agriculture: revisiting WHO guidelines. Water Science and Technology, 50(2), 31.

Chatterjee, C., Triplett, R., Johnson, C. K., \& Ahmed, P. (2017). Willingness to pay for safe drinking water: A contingent valuation study in Jacksonville, FL. Journal of environmental management, 203, 413-421.

Coulibaly, O., Nouhoheflin, T., Aitchedji, C. C., Cherry, A. J., \& Adegbola, P. (2011). Consumers' perceptions and willingness to pay for organically grown vegetables. International journal of vegetable science, 17(4), 349-362.

Ensink, J. H., Mahmood, T., Van der Hoek, W., Raschid-Sally, L., \& Amerasinghe, F. P. (2004). A nationwide assessment of wastewater uses in Pakistan: An obscure activity or a vitally important one? Water policy, 6(3), 197-206.

Frew, E. J., Whynes, D. K., \& Wolstenholme, J. L. (2003). Eliciting willingness to pay: comparing closed-ended with open-ended and payment scale formats. Medical Decision Making, 23(2), 150-159.

Government of Balochistan. Development Statistics of Balochistan 2015-16. http://balochistan.gov.pk/index.php?option=com_docman\&task=cat_view\&gid $=1686 \&$ Itemid $=677$

Gupta, N., Khan, D. K., \& Santra, S. C. (2008). An assessment of heavy metal contamination in vegetables grown in wastewater-irrigated areas of Titagarh, West Bengal, India.Bulletin of Environmental Contamination and Toxicology, 80(2), 115-118.

Järup, L. (2003). Hazards of heavy metal contamination. British medical bulletin, 68(1), 167-182.

Khan, G., Khan, M. Jawad, \& Khan, M. Ayaz. (2018) Willingness to pay for improved solid waste management in Quetta. BUITEMS, Unpublished Thesis 
Kakar, S. R., Wahid, A., Tareen, R. B., Kakar, S. A., Tariq, M., \& Kayani, S. A. (2010). Impact of municipal wastewater of Quetta city on biomass, physiology and yield of canola (Brassica napus L.). Pak. J. Bot, 42(1), 317-328.

Khalil, S. (2011). Agricultural use of untreated urban wastewater in Pakistan. Asian Journal of Agriculture and Rural Development, 1(1), 21.

Khan, H. (2014). Estimating elasticities of demand and willingness to pay for clean drinking water: empirical evidence from a household level survey in northern Pakistan. Water and environment journal, 28(1), 145-152.

Khan, S., Cao, Q., Zheng, Y. M., Huang, Y. Z., \& Zhu, Y. G. (2008). Health risks of heavy metals in contaminated soils and food crops irrigated with wastewater in Beijing, China. Environmental pollution, 152(3), 686-692.

Lagerkvist, C. J., Hess, S., Okello, J., \& Karanja, N. (2013). Consumer willingness to pay for safer vegetables in urban markets of a developing country: The case of Kale in Nairobi, Kenya. The Journal of Development Studies, 49(3), 365-382.

Muchuweti, M., Birkett, J. W., Chinyanga, E., Zvauya, R., Scrimshaw, M. D., \& Lester, J. N. (2006). Heavy metal content of vegetables irrigated with mixtures of wastewater and sewage sludge in Zimbabwe: implications for human health. Agriculture, Ecosystems \& Environment, 112(1), 41-48.

Mustafa, U., Ahmad, I., \& ul Haq, M. (2014). Capturing willingness to pay and its determinants for improved solid waste management (No. 2014: 110). Pakistan Institute of Development Economics.

Nicholson, W., \& Snyder, C. (2011). Microeconomic theory: Basic principles and extensions. Nelson Education.

Nolan, K. R. (1983). Copper toxicity syndrome. Journal of Orthomolecular Psychiatry, 12(4), 270-282.

Ogwuegbu, M. O. C., \& Muhanga, W. (2005). Investigation of lead concentration in the blood of people in the Copperbelt Province of Zambia. J Environ, 1, 66-75.

Pakistan Bureau of Statistics. Population Census, 2017. Retrieved on $17^{\text {th }}$ September 2018. http://www.pbscensus.gov.pk/

Singh, A., Sharma, R. K., Agrawal, M., \& Marshall, F. M. (2010). Risk assessment of heavy metal toxicity through contaminated vegetables from wastewater irrigated area of Varanasi, India. Tropical Ecology, 51(2), 375-387.

Xie, B. C., Zhao, W., \& Liu, L. Q. (2017, June). Willingness to Pay for Green Electricity Based on Contingent Valuation Method: Case Study of Tianjin, China. In Meeting the Energy Demands of Emerging Economies, 40th IAEE International Conference, June 18-21, 2017. International Association for Energy Economics.

Yahaya, I. (2008). Measuring Consumers' Willingness to pay for "Safer" Vegetables in Urban and Peri-Urban Ghana (Doctoral dissertation). 